\title{
Article
}

\section{Factors impacting on cleaner production: Case studies of Chinese pharmaceutical manufacturers in Tianjin, China}

\author{
Li, X and Hamblin, David
}

Available at http://clok.uclan.ac.uk/19699/

Li, X and Hamblin, David ORCID: 0000-0002-4897-1725 (2016) Factors impacting on cleaner production: Case studies of Chinese pharmaceutical manufacturers in Tianjin, China. Journal of Cleaner Production, 131 . pp. 121132. ISSN 0959-6526

It is advisable to refer to the publisher's version if you intend to cite from the work. http://dx.doi.org/10.1016/j.jclepro.2016.05.066

For more information about UCLan's research in this area go to http://www.uclan.ac.uk/researchgroups/ and search for <name of research Group>.

For information about Research generally at UCLan please go to http://www.uclan.ac.uk/research/

All outputs in CLoK are protected by Intellectual Property Rights law, including Copyright law. Copyright, IPR and Moral Rights for the works on this site are retained by the individual authors and/or other copyright owners. Terms and conditions for use of this material are defined in the policies page.

\section{CLoK}

Central Lancashire online Knowledge www.clok.uclan.ac.uk

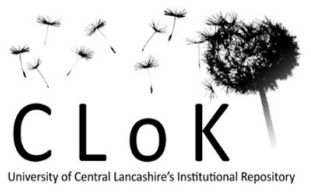




\section{Factors impacting on cleaner production: case studies of Chinese pharmaceutical manufacturers in Tianjin, China}

LI, Xiaohong <http://orcid.org/0000-0001-8148-7348> and HAMBLIN, David

This document is the author deposited version. You are advised to consult the publisher's version if you wish to cite from it.

\section{Published version}

LI, Xiaohong and HAMBLIN, David (2016). Factors impacting on cleaner production: case studies of Chinese pharmaceutical manufacturers in Tianjin, China. Journal of Cleaner Production, 131, 121-132. 


\title{
Factors impacting on cleaner production: case studies of Chinese pharmaceutical manufacturers in Tianjin, China
}

\author{
Xiaohong $\mathrm{Li}^{\mathrm{a}^{*}}$ and David Hamblin ${ }^{\mathrm{b}}$ \\ ${ }^{\text {a }}$ Sheffield Business School, Sheffield Hallam University, Sheffield, United Kingdom, \\ E-mail: x.li@shu.ac.uk, +44 1142253106 \\ ${ }^{b}$ Lancashire Business School, University of Central Lancashire, Preston, United Kingdom \\ ${ }^{*}$ Corresponding author
}

\begin{abstract}
The literature contains a number of studies exploring factors impacting on cleaner production, but few studying these factors simultaneously. This study has identified these factors in the literature and represented their relationships with cleaner production in a conceptual framework. The key factors included in this framework are ISO14001 certification, eco-innovation of product and process, industrial and government regulations, and environmentally-friendly culture. Nine major Chinese pharmaceutical companies in Tianjin, China, have been used as case study companies to explore the impact of these key factors on cleaner production. The analysis reveals that companies that have ISO14001 certification are likely to be one step ahead; however ISO14001 certification is not the only factor leading these manufacturing companies to be active in cleaner production. It is green process innovation rather than product innovation that directly impacts on cleaner production. The environmentally-friendly culture significantly influences the promotion of cleaner production. It is concluded that the industry needs to promote process-oriented innovations and build environmentally-friendly culture in order to be more active in cleaner production in the long-run. This paper provides case-based insight for cleaner production and environmental sustainability researchers and the strategic direction for manufacturing companies to achieve cleaner production and environmental sustainability.
\end{abstract}

\section{Keywords}

Cleaner production, Process innovation, ISO14001, Environmentally-friendly culture

\section{Highlights:}

1. The study explores key factors impacting on cleaner production.

2. Process innovation impacts cleaner production more profoundly than product innovation.

3. ISO14001 certified companies are one step ahead in cleaner production.

4. ISO14001 is not the only way for companies to be active in cleaner production.

5. An environmentally-friendly culture promotes cleaner production.

The total word count: 11,254 including the title page, acknowledgement, tables and appendices. 


\section{Introduction}

Promoting cleaner production in companies is particularly important for improving environmental performance within companies, along their supply chains, and to wider society. Understanding factors impacting on cleaner production enhances the promotion of cleaner production. The cleaner production literature, to some extent, has explored the impact of specific factors, including green product and process innovations, use of international standards, regulations, and environmentally-friendly culture on the cleaner production. In particular, green product innovation contributes to cleaner production in either one or all of the following: energy minimisation, material reduction, and pollution prevention (Dangelico and Pujari, 2010). Green production process reduces material, energy and water usage and generates less waste through the improved process efficiency (Chowdary and George, 2012). The use of International Standards Organisations (ISO)'s ISO14001 environmental management system (EMS) has impacted positively on manufacturing companies' environmental performance (Vries et al., 2012). Enforcement of industrial and government regulations influences companies' environmental effort (Abreu, 2009; Testa et al., 2012). The lack of environmentally-friendly culture creates a barrier for promoting cleaner production in organisations (Lober, 1998; Vieira and Amaral, 2016).

This study aims to explore the impact of key factors on cleaner production, at the unit of analysis of the firm. Environmentally beneficial or green product and process innovations, also termed eco-innovations, the use of ISO14001, industrial and government regulations, and environmentally-friendly culture appear to be four key factors impacting on manufacturing companies' cleaner production. Research has been published in exploring the impact of one or two of these four key factors on cleaner production (Chowdary and George, 2012; Dangelico and Pujari, 2010; Lober, 1998; Vries et al., 2012). However, there has been no published empirical research which has studied the impact of these factors simultaneously on cleaner production and not within the pharmaceutical industry.

Pharmaceutical manufacturers share commonality in terms of production process with some other manufacturing companies, from preparing raw ingredients, mixing and filling, and finally packaging (Amstead et al., 1987). However, they generate unique wastes in the production process, such as solvent water and residue waste at the end of the production process. In addition, most drugs, medicines or intermediates contain some chemical compounds which are likely to be toxic or polluting to the environment if no actions have been taken to degrade those unsold or returned (Fatta-Kassinos et al., 2011). The industry presents a substantial opportunity for improving its environmental footprint by considering implementing prevention-based approaches, reducing the disposal of residual wastes and solvent water, and degrading unused and returned products (Fatta-Kassinos et al., 2011; Kreisberg and Zheng, 2011). Therefore, a cleaner production study in this industry is particularly relevant to achieving cleaner production and environmental sustainability.

The rapid economic growth in China over the last three decades is coupled with a large increase in the overall volume of manufacturing activities. This has caused significantly increased pollution in most major cities in China (Yu and Wen, 2010). Effectively reducing pollution in major cities is therefore very critical for pollution reduction in China. Therefore, we have selected pharmaceutical manufacturing companies in Tianjin, a major city and a centre of the pharmaceutical industry for over a century, as our case study companies. Most Chinese pharmaceutical manufacturers produce both modern Chinese medicines and western medicines, where the manufacturing processes are similar, except for generating a greater 
amount of residue waste when producing Chinese medicines. The generic process applicable to both product streams is described in Figure 1.



*. Carbon dioxide $\left(\mathrm{CO}_{2}\right)$

Figure 1. A process map of the pharmaceutical production process and critical control points of wastage and pollution (developed from a visit to one Tianjin Chinese pharmaceutical manufacturing company in 2012)

The production process generally contains six key production stages, from 'preparing ingredients and mixture' to 'labelling and packaging' (see the six text boxes in Figure 1). Along this production process, there are a number of positions which can be controlled by companies in terms of wastage and pollution generation and we term these points as critical control points (see the numbered items from 1 to 6 in Figure 1). This process map with critical control points was developed in this study based on a visit to one of the pharmaceutical manufacturers in Tianjin. This process map, which illustrates the production process for pharmaceutical manufacturers, is also generic in a way as it shares similarities with many types of manufacturing processes (Department of the Environmental-Industrial Profile, 1995; Amstead et al., 1987). The map helps to understand cleaner production of pharmaceutical manufacturers discussed in this paper.

In order to achieve the research aim, this study proposes a conceptual framework derived from the literature (Shields, 1998), and employs a non-linear, multiple stage case research model (Stuart et al., 2002). The conceptual framework describes the impact of each of the four factors on cleaner production. A comparison is made between the data from the case 
study organisations and the relationships presented in the conceptual framework which facilitates discussions to achieve the research aim.

This paper contributes to the cleaner production literature through exploring key factors impacting on cleaner production. In particular, this study improves understanding of the roles of ISO14001 certification, eco-innovation of green product and process, the regulatory environment, and environmentally-friendly culture impacting on cleaner production. This study has used a qualitative, single comparative case study to establish relationships between these key factors and cleaner production, which contributes to theory building and refinement. This paper explores whether these factors impact on cleaner production and most importantly on how and why these factors impact on cleaner production. The findings can be used for academic researchers to undertake further research in this study field, for example, to make a comparison between different industries or different countries. The findings can also be used as a basis to establish hypotheses to be tested using a large survey sample in order to quantify the strength of the causal relationships between these factors and cleaner production and environmental and firm performance ( $\mathrm{Li}$ and Hamblin, 2001 and 2003). The findings can also be used for companies to understand and improve their cleaner production in order to generate more effective strategies and practices to enhance their environmental performance results.

The next section reviews the literature and presents the conceptual framework. A non-linear, multiple-stage case research model is explained in the methods section, followed by the case study company profiles. The data results are presented and discussed by analysing and comparing to the literature findings summarised in the conceptual framework. Conclusions are drawn and further research areas are proposed at the end.

\section{Literature review}

First of all, we clarify the meaning of the concept of cleaner production for this research. Cleaner production considers all decisions, activities and actions associated with improving environmental performance through reducing negative impact on the environment, not just pollution control activities of a production process. This is consistent with the definition by Ortolano et al. (1999) which is 'making efforts to avoid adverse environmental impacts throughout a product's life cycle - from raw material extraction, through product design, manufacture, and use and finally to product disposal' (page 432). In this paper, we focus on decisions, activities and actions of reducing negative impacts on environment, specifically relating to products and their production processes.

This literature review is organised in five sub-sections. The first four sub-sections review ISO14001, eco-innovation of product and process, industrial and government regulations, and environmentally-friendly culture and their impacts on cleaner production. The review places a particular emphasis on China and the pharmaceutical industry. The last sub-section presents the conceptual framework and proposes the research questions.

\subsection{ISO14001 certification: benefits and its trend in China}

ISO14001 is a voluntary international standard for developing, establishing, and maintaining an effective EMS in organisations worldwide (ISO14001, 2004). Since ISO14000 series were introduced in 1996, ISO14001 has been used in many organisations in different industries in different countries to develop and maintain their EMSs (ISO survey, 2012). The benefits of implementing a certified ISO14001 have been widely recognised. These include: 
(1) improved market position through a better public image of corporate responsibility,

(2) increased environmentally sustainable practices,

(3) improved employee awareness of environmental issues,

(4) enhanced social sustainability by establishing a better relationship with society, and

(5) enhanced economic sustainability (Psomas et al., 2011; Searcy et al., 2011).

Implementing the ISO14001 certification has a positive impact on cleaner production and also contributes to social sustainability and economic sustainability (Psomas et al., 2011; Searcy et al., 2011). These benefits explain the increase of the number of firms being ISO14001 certified at a virtually exponential rate in China over the last decade (see Figure 2).

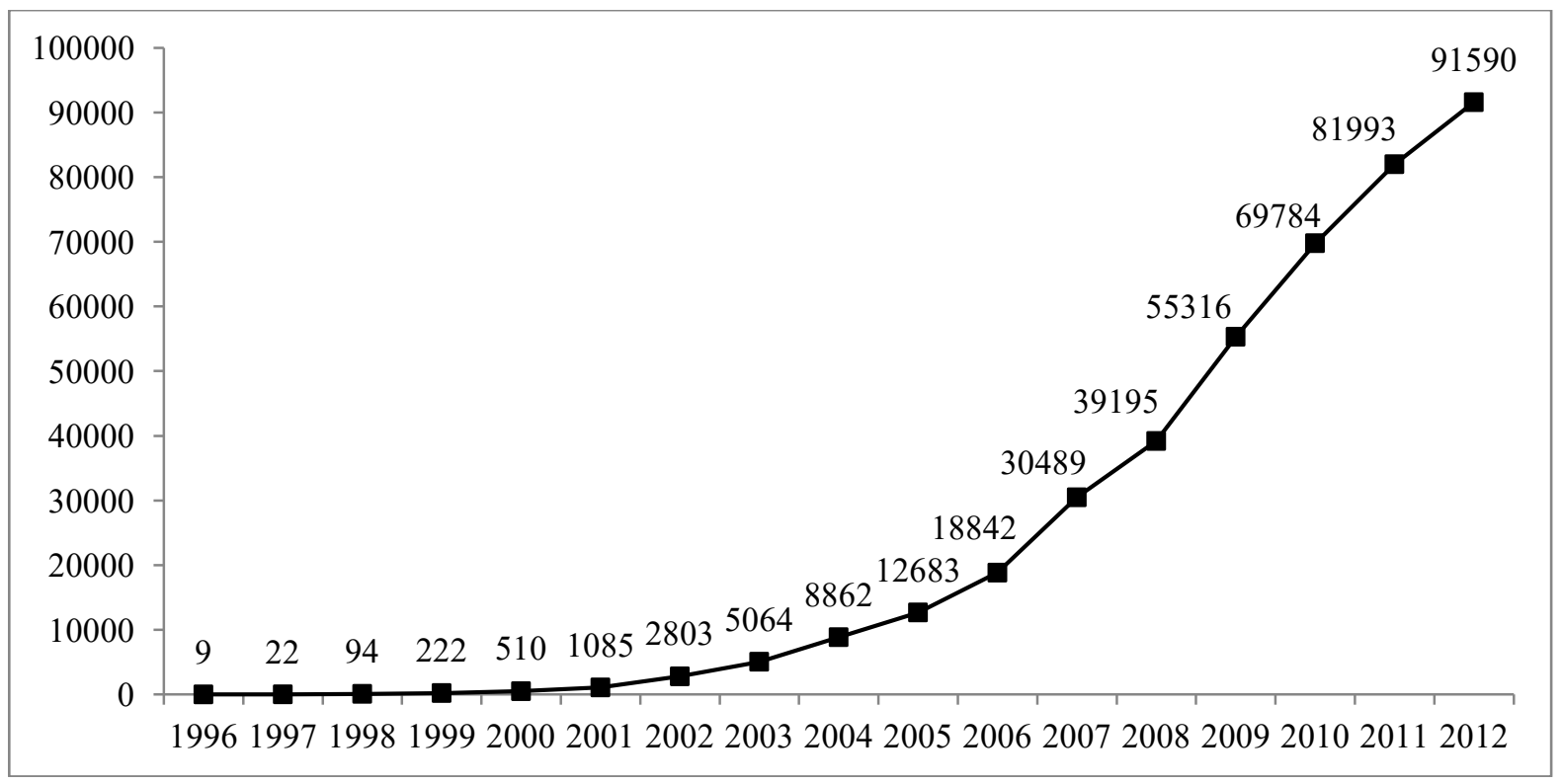

Figure 2. The number of companies certified with ISO14001 in China from 1996 to 2012 (Raw data extracted from ISO survey, 2012)

Even in the early years of implementation of ISO14001 in China, firms with certified EMS had managed their environmentally-based daily activities much more effectively, and had a positive impact on environmental performance (Matouq, 2000). Implementing voluntary international standards can be very costly to firms (Vastag and Melnyk, 2002). Benefits must be greater than costs to result in an increased number of firms gaining and maintaining ISO14001 certification globally. Based on a large Chinese company database over a five-year period, a study confirmed that ISO14000 certification has significantly contributed to the firm's profitability (Yang and Yao, 2012).

Overall, the certification of ISO14001 in China has dramatically increased over the recent decades. However, the number of companies with ISO14001 certification is still limited compared to the total population due to limited human and financial resources available in a developing country (Massoud et al., 2010). Nevertheless, the benefits of being certified ISO 14001 are clearly recognised in the literature.

\subsection{Eco-innovation and cleaner production}

Eco-innovation includes many types of innovation which explicitly emphasise the reduction of environmental impact, ranging from innovations in products, processes, marketing and 
organisational methods to social and institutional structures (Kesidou and Demirel, 2012). Developing green products contributes to reduction of materials and energy usage and pollution prevention along a product life cycle (Dangelico and Pujari, 2010). Products have their development, production, consumption and disposal life cycle. Eco-innovation improvement at any stage of this life cycle contributes to cleaner production. This research focuses on product development and production stages. As far as product development is concerned, eco-innovation refers to new or improved product designs with conscious consideration of using eco-friendly materials and increased possibilities for recycling and reuse at the end of product life cycle (Romli et al., 2015). For production processes, ecoinnovation refers to conscious consideration of improving eco-efficiency of a production process (Dencic, et al., 2014). An improved eco-efficiency production process reduces the use of materials, energy and water, leading to less wastage and pollution, which can be achieved through improved production planning approaches and use of technology (Dencic, et al., 2014; Grundemann, et al., 2009). Different companies may have different designs of products and produce their products using different processes and technologies, which result in different environmental performance in terms of material, energy and water usage and waste and pollution generation (Ekins, 2010). Both green products and processes are relevant to pharmaceutical manufacturing companies, through developing new medicines and investing in green technologies for production processes.

Eco-innovations can be either 'end-of-pipeline' approaches or process-oriented 'integrated' methods, or some in between (Van Hoek, 1999). Most 'end-of-pipeline' approaches are reactive and are pollution control-oriented. Process-oriented 'integrated' methods are preventive in nature and reduce amount of waste generated in the first place (Lober, 1998). Hence, process-oriented preventive approaches are more effective than 'end-of-pipeline' approaches in terms of longer term environmental performance improvement of a company and along its supply chain (Lee and Rhee, 2005).

As far as China is concerned, green process innovation has been explored in terms of its contribution to cleaner production in Chinese firms. For example, green production process innovation has been made in the coal-fired electricity industry in China (Yu et al., 2011). Their study concluded that eco-innovation led to a more efficient production process and was the determinant in decreasing resource use and environmental impact (Yu et al., 2011). There are industry level studies directly exploring eco-innovations in the pharmaceutical industry in China (Hu and Phillips, 2011; Suthar and Singh, 2012). The use of bio-fuel has contributed to Chinese pharmaceutical companies' cleaner production significantly since 2000 (Hu and Phillips, 2011). The developed phytotoxicity screening method composted herbal pharmaceutical industry waste to be used in the crop production (Suthar and Singh, 2012).

However, Altenburg et al. (2007) found that mounting innovation efforts only rarely materialised in cutting-edge innovations in China but suggested that if capital accumulation proceeded at the current pace, innovation capabilities would rapidly be built up in China (Wang et al., 2010). With the increased awareness of environmental issues in China, these innovation capabilities will certainly enhance eco-innovation and have a positive impact on future cleaner production in China (Wang et al., 2010).

\subsection{Environmental related regulations for the Chinese pharmaceutical companies}

The pharmaceutical industry has long been and still is one of the most extensively regulated industries amongst all (Vogel, 1998). Each country has their own regulations regarding drug development and production. China established the State Drug Administration (SDA) in 
1998, which was renamed the State Food and Drug Administration (SFDA) in 2003. SDA issued the Good Manufacturing Practices (GMP) regulations in 1999. GMP is an international standard for production and testing practices that help to ensure quality products. Many countries have legislated pharmaceutical and medical device companies to follow GMP procedures, and these countries have created their own GMP guidelines. China's Drug Administration Law states that all pharmaceutical manufacturers must meet and follow the national GMP standards. When applying the national GMP certification in China, a description of the air-cleaning system and water systems, and an environmental production certificate, are required, besides other documents (Liang, 2006). Therefore, the China's national GMP requires Chinese pharmaceutical manufacturers to reach a certain standard in cleaner production, represented in the requirements of air-cleaning systems, water systems and production processes.

The cleaner production strategy (the CP strategy) has become a key strategy in Chinese policy development since the United Nations Conference on environment and development took place in 1992 (Wang, 1999). 'The CP strategy' in China includes a new policy framework for industrial development and environmental protection (Wang, 1999). A significant number of Chinese enterprises have adopted 'the CP strategy' to measure and improve their production processes and have achieved substantial reductions in pollution. However, it was only a starting point of a long journey of pollution prevention and reduction in China at that time. Many barriers, such as knowledge and awareness, regulatory impediments, financial resources, technological hurdles and organisational barriers were identified for that time period (Wang, 1999). The enforcement of regulations has been made since then. For the pharmaceutical industry, this includes the implementation of the compulsory national GMP standards into practice in 2003; the issue of the current GMP (cGMP) which is a European standard but not compulsory in 2010; and the promotion of ISO14000 series from 2012 to the present day.

The Chinese government has adopted the principle of a 'circular economy' and has used strategic environmental assessment (SEA) as a tool to reinforce governmental policy development (Hong and Li, 2013; Ren et al., 2010). 'Circular economy' is a generic term for the reducing, reusing, and recycling activities conducted in the process of circulation, consumption, and production (Hong and Li, 2013, page 129). The policy switches 'fast and well' to 'well and fast' economic development (Ren et al., 2010). Even though there is still a long way to go, an awareness of environmental issues by companies has been dramatically enhanced over the last few years in China, with the enforcement of industrial government regulations and policies (Hong and Li, 2013; Ren et al., 2010).

\subsection{Environmentally-friendly culture and cleaner production}

The management literature indicates that the organisational culture impacts on the adoption of management approaches in companies (Stirzaker, et al, 2011). Organisational culture contains multiple dimensions, including communication between employees and management teams, employee participation, management commitment, and strategic importance of organisational goals (Ginevičius and Vaitkūnaite, 2006).

Pollution prevention, particularly in relation to its strategic importance to companies, has long been recognised as an important dimension of organisational culture and an opportunity for entrepreneurship (Deltas et al, 2014; Lober, 1998). The development of an environmentally-friendly culture needs to be supported at the corporate and strategic level in order for any cleaner production initiatives to be successful (Stone, 2000). 
Environmentally-friendly culture makes a positive impact on environmental quality through conscious engagement in reducing the level of consumption and enhancing the consideration of sustainability (Schumacher, 2015). Environmentally-friendly culture is more likely to impact positively on the companies' environmental performance and contributes to companies' operational and marketing performance (Fraj et al, 2011). The lack of the environmentally-friendly culture creates barriers for an organisation's commitment to cleaner production (Lober, 1998; Vieira and Amaral, 2016).

Organisational culture, particularly environmentally-friendly culture, is complex and multidimensional. As far as this research is concerned, the environmentally-friendly culture is characterised by a company's outlook towards its role of being ethical to the environment and practising good citizenship (Ajami, 2007; Thomas, 2002) as well as taking cleaner production and environmental sustainability as strategically important to the company's business development (Lober, 1998).

\subsection{The conceptual framework and research questions}

The literature clearly supports the positive impact of the use of ISO1400, eco-innovation of product and process, industrial and government regulations, and environmentally-friendly culture on manufacturing companies' cleaner production. Therefore, we embrace these literature findings into a conceptual framework.

Our conceptual framework contains four propositions which summarise the relationships between the four key factors and cleaner production, derived from the literature (Figure 3). This conceptual framework is used to represent the four propositions in an overall framework to be compared with experiences of the case study organisations. Recognition of variations between practices of empirical case companies and relationships represented in the conceptual framework aids understanding of the underlying reasons and supports recommendations for organisations in practice. According to Shields (1998), the use of the conceptual framework increases the reliability and validity of the data analysis through the systematic comparison of practice to existing theories.

1. The use of ISO14001 positively impacts on manufacturing companies' environmental performance (Psomas et al., 2011; Yang and Yao, 2012).

2. Eco-innovation, particularly green product and process innovations, positively impacts on waste/pollution reduction and energy usage (Dangelico and Pujari, 2010).

3. Enforcement and promotion of GMP, cGMP, 'the CP strategy' enforce pharmaceutical companies to pursue their cleaner production (Hong and Li, 2013; Wang, 1999).

4. Developing an environmentally-friendly culture reduces barriers for organisations in developing and implementing cleaner production (Lober, 1998; Stone, 2000; Vieira and Amaral, 2016).

Figure 3. The conceptual framework of the four propositions derived from the literature 
In order to explore these propositions, we put forward the following research questions to explore 'why' and 'how' each of these four key factors has impacted on cleaner production:

1. How does the international standard of ISO14001 impact on cleaner production?

2. Which type of innovation, product or process or both, contributes more profoundly to cleaner production and why?

3. How do the industrial and government regulations shape cleaner production?

4. How does the environmentally-friendly culture make a difference in cleaner production?

The next section presents methods used for the investigation of these research questions in order to achieve the research aim of the exploration of factors impacting on cleaner production.

\section{Methods}

A non-linear five-stage case research process model is developed for this research (see Figure 4). It is based on the five-stage case research process model proposed by Stuart et al. (2002, page 420) for conducting Operations Management research. The non-linear feature is frequently presented in case research studies in Operations Management research (Seuring, 2008). This provides continuous improvement opportunities for the work conducted at early stages. The repetition of stages ensures the rigor of the case research method in practice and allows the theoretical constructs to form in order to achieve the research aim more profoundly (Seuring, 2008). This non-linear approach for case study research also improves the reliability of the research process and validity of the research findings because of continuous improvement of research stages until the final conclusions can be drawn. The case research process for this study is explained below.

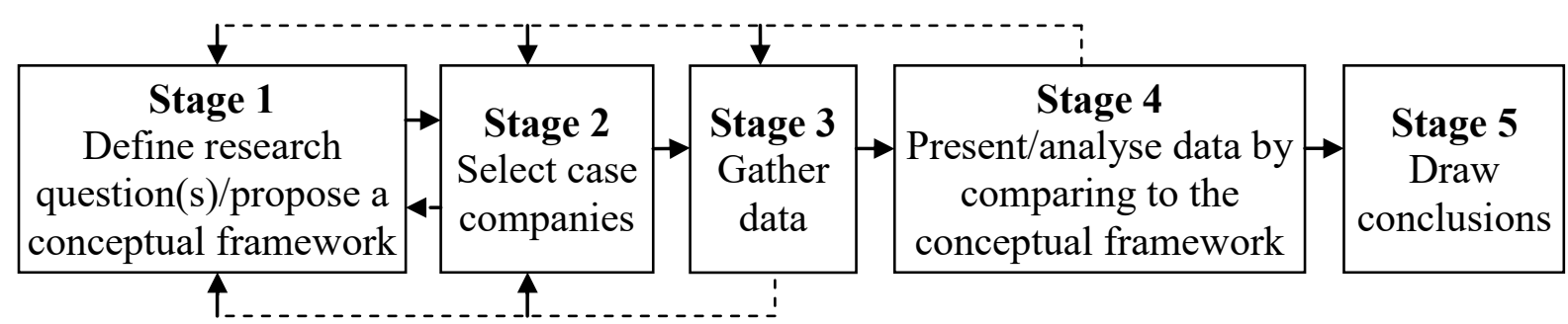

Figure 4. The non-linear five-stage case research process model (developed from Stuart et al., 2002, page 420)

Stage 1-define the purpose of the research, (re)define research question(s), and propose the conceptual framework from the literature

The general purpose of a research can be theory building, theory testing, theory refinement or a combination of any two or three of these (Meredith, 1998; Voss et al., 2002). A case study method is a primary method to theory building in the Operations Management field (Meredith, 1998; Stuart et al., 2002) and used widely for theory refinement (Meredith, 1998). We consider that our research fits into theory building and has some elements of theory refinement; however it is not for theory testing (Seuring, 2008; Voss, et. al., 2002). This is because some studies explored the factors of eco-innovation, ISO14001, industrial and government regulations, and environmentally-friendly culture individually rather than collectively in the context of China (Hu and Phillips, 2011; Qi et al., 2011; Suthar and Singh, 2012; Wang, 1999; Wang et al., 2010; Zeng et al., 2005). This research intends to explore these factors simultaneously and explore 'why' and 'how' questions regarding these factors, 
not just simple 'what' questions. Therefore, case research is an appropriate research method for this study.

The conceptual framework embracing the key factors and their impact on the matter concerned is developed at this stage. The conceptual framework contains propositions to be investigated, supporting the generation of the research questions.

\section{Stage 2-select case studies}

The decision of conducting this research in Tianjin was made because Tianjin is a welldeveloped city in China, where good cleaner production practices can be easily captured for the research purpose. It is also because of its accessibility to a number of manufacturing companies. There are 22 major pharmaceutical manufacturing companies in Tianjin. Nine of these 22 companies returned questionnaires within one month and were willing to answer further questions if needed. For confidentiality, the companies are coded A to I. The company profiles are given in the next section.

We can claim our sampling method as a 'convenience sampling' method (Voss et al., 2002). This sample contains 41 per cent of the total population of the major pharmaceutical manufacturing companies in Tianjin. We aimed to include some companies which are ISO14001 certified. We also aimed to include some companies which have been involved in cleaner production decisions, activities and actions in the past few years. Five companies in these nine are ISO14001 certified. Seven out of these nine companies have implemented some cleaner production decisions, activities and actions over the last five years. Therefore, both criteria for sampling, which are the ISO14001 certification and involvement in cleaner production decisions, activities and actions, have been satisfied.

\section{Stage 3-design questionnaire and gather data}

We employed a questionnaire approach for our data collection. Two questionnaires were used. The first one collected general information of the companies (Appendix 1), which contributed to the characterisation of the company profiles for this study. Additional information from other documentation regarding companies was also collected to complete the company profiles. The second questionnaire specifically investigated an individual company's cleaner production decisions, activities and actions using six open-ended questions (Appendix 2).

In the second questionnaire, the first question is concerned with the usage of an EMS, which targets the first research question regarding ISO14001 EMS and equivalent systems used. Question 2 investigates the decisions, activities and actions implemented over the last 5 years for improving the production process towards cleaner and greener production. Question 3 explores specific technologies or processes employed in companies in order to respond to the environmental regulations, legislation, and policies. Question 4 investigates the difference in the production process between producing new and old products in terms of the level of 'cleaner production'. Questions 2 to 4 aim to explore the second research question, regarding product and process innovations. Question 5 is specifically concerned with the industrial and government regulations for the pharmaceutical industry, and is associated with the third research question. Question 6 explores the outlook of environmentally-friendly culture by companies through investigating the perceived strategic importance of achieving good global citizenship and the most important considerations for their businesses. Question 6 serves to investigate the fourth research question. 
One company visit was made prior to design of this research and questionnaire. A working relationship has been established with a local experienced researcher, who works in a biotechnological institute in Tianjin. The local researcher works as a coordinator with industries and therefore has external working relationships with these pharmaceutical manufacturing companies and acted as the local link for data collection. Discussions of required data and standards were held prior to the data collection to ensure the quality and reliability of the data collected. Continual contact with the local researcher has been maintained throughout and after the data collection. Other communications have also been made to collect additional information, whenever required, to explore 'why and 'how' questions in depth. While there are inherent risks in using a third party for data collection, we mitigated the risk to a minimum through monitoring the process closely to ensure the reliability and validity of the data collected.

Stage 4-present and analysis data by comparing to the conceptual framework The data collected for the six questions are presented. We employ the tabulate method to present, classify and compare the data amongst companies. The results from the nine companies of six questions are classified and synthesised to address the four propositions presented in the conceptual framework (Figure 3).

The method used is the guided analysis following the pre-established propositions in a developed conceptual framework. The data relating to each of the propositions and the corresponding research question are synthesised among these nine companies and comparing to the literature findings. The discussions focus on the achievement of the research aim which explores factors impacting on the cleaner production. We summarise the relationships between the key factors and cleaner production in a graphic format to complete the analysis.

\section{Stage 5-draw conclusions}

Conclusions are drawn based on the findings generated at stage 4 . We focus on the four key factors identified in the literature and their impact on cleaner production decisions. The identified factors which impact on these companies' cleaner production can be lessons for other manufacturing companies. The contributions of this research are specified in the conclusions, along with future research opportunities.

\section{Case study company profiles}

The case study companies include four private-owned, one joint venture and four state-owned enterprises (see Table 1). Two of the state-owned companies have a long history of producing Chinese medicines and were private-owned companies prior to 1949. These companies produce variety of medicines and the majority produce both Chinese and western medicines. Six of them have export business. Table 1 summarises the characteristics of these case study companies' profiles. 


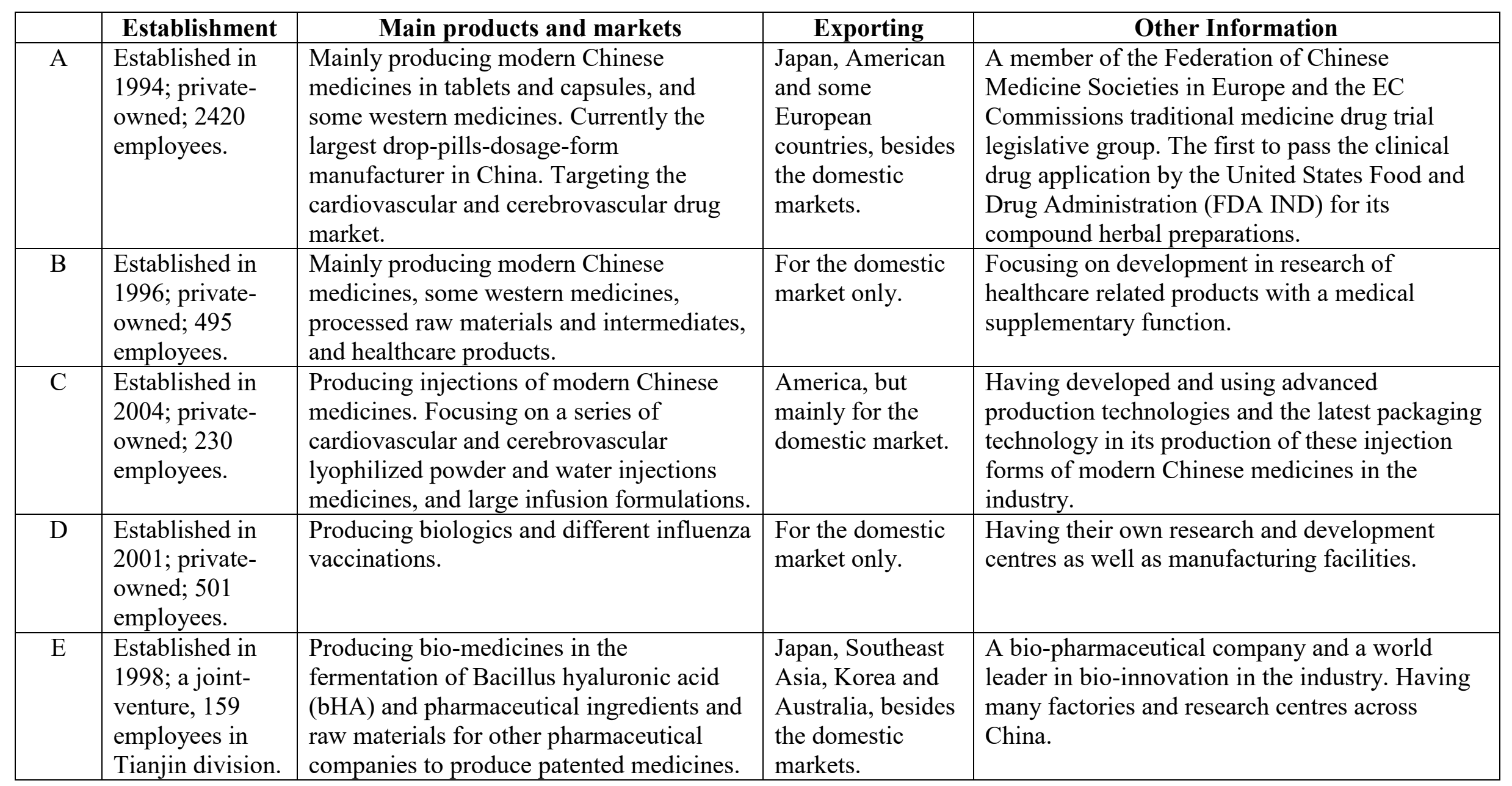




\begin{tabular}{|c|c|c|c|c|}
\hline & Establishment & Main products and markets & Exporting & Other Information \\
\hline $\mathrm{F}$ & $\begin{array}{l}\text { Established in } \\
1833 \text { as a } \\
\text { private-owned; } \\
\text { became state- } \\
\text { owned in early } \\
50 \mathrm{~s} ; 286 \\
\text { employees. }\end{array}$ & $\begin{array}{l}\text { Producing modern Chinese medicines in } \\
\text { liquids, tablets, and granules of } 88 \\
\text { products, ranged from treating colds and } \\
\text { flues to diabetes and urinary tract } \\
\text { infections. }\end{array}$ & $\begin{array}{l}\text { Many Eastern } \\
\text { countries but also } \\
\text { New Zealand, } \\
\text { besides the } \\
\text { domestic markets. }\end{array}$ & $\begin{array}{l}\text { Having invested significantly in research on } \\
\text { Chinese medicine formulations reform } \\
\text { exploration and technology in 1950s. Having } \\
\text { developed its first tablet formulation of } \\
\text { traditional Chinese medicines (TCM) in } 1952 .\end{array}$ \\
\hline $\mathrm{G}$ & $\begin{array}{l}\text { Established in } \\
1914 \text { as a } \\
\text { private-owned; } \\
\text { became state- } \\
\text { owned in early } \\
50 \text { s; } 288 \\
\text { employees. }\end{array}$ & $\begin{array}{l}\text { Producing modern Chinese medicines in } \\
\text { eight formulations: ointments, capsules, } \\
\text { pills, syrups, mixture, wine agents, plaster, } \\
\text { and liniment, with more than } 90 \text { varieties. } \\
\text { Having eight unique patent varieties and } \\
\text { four state-protected products. }\end{array}$ & $\begin{array}{l}\text { America, } \\
\text { Indonesia, Africa, } \\
\text { and Malaysia, } \\
\text { besides the } \\
\text { domestic markets. }\end{array}$ & $\begin{array}{l}\text { Australia and Bavaria GMP certification in } 1994 \\
\text { and 1996. The first in Tianjin to pass the 'the } \\
\text { most purification' certificate of Germany and } \\
\text { Australia GMP standard. }\end{array}$ \\
\hline $\mathrm{H}$ & $\begin{array}{l}\text { Established in } \\
\text { 1992; state- } \\
\text { owned majority } \\
\text { share; Israeli } \\
\text { shareholder; } 156 \\
\text { employees. }\end{array}$ & $\begin{array}{l}\text { Specialised in developing and } \\
\text { manufacturing anti-viral and anti-tumour } \\
\text { drugs. Producing the key product of the } \\
\text { second generation of genetically } \\
\text { engineered interferon } \alpha-2 b \text {. }\end{array}$ & $\begin{array}{l}\text { Europe, America, } \\
\text { Africa and other } \\
\text { Asian countries, } \\
\text { besides the } \\
\text { domestic market. }\end{array}$ & $\begin{array}{l}\text { Investing in the international standard production } \\
\text { lines. }\end{array}$ \\
\hline $\mathrm{I}$ & $\begin{array}{l}\text { Established in } \\
\text { 2007; state- } \\
\text { owned; } 57 \\
\text { employees. }\end{array}$ & $\begin{array}{l}\text { Producing more than } 30 \text { plant extracts and } \\
\text { also finished products in tablets, capsules } \\
\text { and granules. Providing specialised } \\
\text { services to other global pharmaceutical, } \\
\text { food and health manufacturing companies. }\end{array}$ & $\begin{array}{l}\text { For the domestic } \\
\text { market only. }\end{array}$ & $\begin{array}{l}\text { Having international advanced precision } \\
\text { analytical equipment in use. Focusing on plant } \\
\text { extracts and pharmaceutical formulations } \\
\text { research development and production operations. }\end{array}$ \\
\hline
\end{tabular}

Table 1. A summary of profiles of case study companies 


\section{Case study results}

This section presents the data collected by the six questions in the second questionnaire regarding companies' cleaner production related aspects. The responses to these six questions have been summarised in Table 2. Some explanations of the data results are provided in this section along with validity of the collected data.

The first column in Table 2 summarises the first question regarding the use of an EMS. Five companies have the ISO14001 certification and four have not had any EMS in use. There is less than four percent of Chinese listed companies which had ISO14001 certified in 2012, based on the most recent published data from the World Bank and the ISO survey of China (World Bank, 2012; ISO survey, 2012). As ISO14001 is an EMS of voluntary international standards, only a small percentage of companies in developing countries have the resources to pursue it (Kim, 2013). Our sample contains a significant percentage of companies which are ISO14001 certified, as we aim to explore ISO14001 and other factors impacting on cleaner production decisions. Including a high number of ISO14001 certified companies increased the validity of research findings through increased relevance to the factor explored.

We consider results from questions 2 and 3 together. Question 2 requires the company to provide cleaner production decisions, activities or actions taken over the past five years and Question 3 asks specific processes or technologies employed by the company to achieve cleaner production targets. The five ISO14001 certified companies have taken at least one cleaner production decisions, activity or actions and have invested in updating specific processes or technologies in recent years (details see Table 2). Two of the four nonISO14001 certified companies, companies F and G, have also implemented cleaner production decisions, activities or actions. However, companies $\mathrm{H}$ and I, neither being certified by ISO14001 nor employing an equivalent EMS, answered 'no' to both questions 2 and 3. Specific cleaner production decisions, activities or actions by these companies are normally unique to each of these companies. However, the general principle is the same as reducing waste at the final disposal stage and reducing water and energy consumption in the production process through improving the process efficiency. These decisions, activities or actions can certainly be shared among pharmaceutical manufacturing companies, particularly for those which have established conditions to be actively engaged in cleaner production. The companies which are not actively engaged in cleaner production certainly need to find a way to become engaged first before considering taking any of these cleaner production decisions, activities or actions to be successfully implementing them.

Question 4 explores whether the companies produce new products greener and cleaner. This includes using less amount of raw ingredients, particularly auxiliary materials for producing Chinese medicines, generating less toxic substances, reducing $\mathrm{CO}_{2}$ emissions, or any other reduction of negative impact on the environment. Companies $\mathrm{A}$ to $\mathrm{G}$ all agreed that producing new products was greener and cleaner when using improved processes and technologies; whereas companies $\mathrm{H}$ and I mentioned that no difference was made for producing new medicines. Companies D, F and G particularly emphasised that achieving cleaner production in producing new products was due to the associated green process innovation. Otherwise, no improvement would have been gained towards cleaner production. This clearly emphasised the importance of green process innovation to green products production and to cleaner production in pharmaceutical manufacturing companies. 


\begin{tabular}{|c|c|c|c|c|c|c|}
\hline & $\begin{array}{c}\text { Q1 } \\
\text { EMS }\end{array}$ & $\begin{array}{c}\text { Q2 } \\
\text { Actions/decisions for } \\
\text { cleaner production }\end{array}$ & $\begin{array}{c}\text { Q3 } \\
\text { Specific process } \\
\text { technology for } \\
\text { cleaner production } \\
\end{array}$ & $\begin{array}{c}\text { Q4 } \\
\text { Cleaner } \\
\text { production of new } \\
\text { products } \\
\end{array}$ & \begin{tabular}{c}
\multicolumn{1}{c}{ Q5 } \\
Industrial \\
regulations \\
/ legislation \\
\end{tabular} & $\begin{array}{c}\text { Q6 } \\
\text { Good global citizenship } \\
\text { and strategic importance } \\
\text { factors } \\
\end{array}$ \\
\hline $\mathbf{A}$ & ISO14001 & $\begin{array}{c}\text { Establishing sewage } \\
\text { treatment stations to } \\
\text { perform sewage water } \\
\text { treatment and recovery, } \\
\text { and water reuse } \\
\text { treatments }\end{array}$ & $\begin{array}{l}\text { Replacing two } \\
\text { traditional coal-fired } \\
\text { industrial boilers by } \\
\text { a three-times more } \\
\text { efficient modern } \\
\text { gas-fired boiler }\end{array}$ & $\begin{array}{l}\text { Yes, and uses the } \\
\text { improved process } \\
\text { to produce new } \\
\text { products }\end{array}$ & GMP & $\begin{array}{l}\text { Yes, and pursue modern } \\
\text { pharmaceutical } \\
\text { technology, and export } \\
\text { performance. }\end{array}$ \\
\hline B & ISO14001 & $\begin{array}{l}\text { Implementing energy } \\
\text { saving initiatives, both } \\
\text { for production and } \\
\text { office operations }\end{array}$ & $\begin{array}{l}\text { Using improved } \\
\text { process technology } \\
\text { for more efficient } \\
\text { energy consumption }\end{array}$ & $\begin{array}{l}\text { Yes, along with } \\
\text { more energy } \\
\text { efficient process }\end{array}$ & GMP & $\begin{array}{l}\text { Yes, and pursue product } \\
\text { quality and people } \\
\text { wellbeing/health. }\end{array}$ \\
\hline $\mathbf{C}$ & ISO14001 & $\begin{array}{l}\text { Implementing various } \\
\text { waste management } \\
\text { initiatives; establishing } \\
\text { an odour reduction } \\
\text { system to reduce the } \\
\text { unpleasant odour in } \\
\text { residue waste }\end{array}$ & $\begin{array}{l}\text { Installing gas } \\
\text { boilers; renovating } \\
\text { high energy- } \\
\text { consumption water } \\
\text { motor pump }\end{array}$ & $\begin{array}{l}\text { Yes, along with } \\
\text { more efficient } \\
\text { boilers and motor } \\
\text { pumps }\end{array}$ & GMP & $\begin{array}{l}\text { Yes, and pursue product } \\
\text { quality and modern } \\
\text { pharmaceutical } \\
\text { technology. }\end{array}$ \\
\hline D & ISO14001 & $\begin{array}{l}\text { Investing in more } \\
\text { environmentally } \\
\text { friendly production } \\
\text { facilities }\end{array}$ & $\begin{array}{l}\text { Using more efficient } \\
\text { production } \\
\text { technology }\end{array}$ & $\begin{array}{l}\text { Yes, but only for } \\
\text { those new products } \\
\text { using the improved } \\
\text { production process }\end{array}$ & GMP & $\begin{array}{l}\text { Yes, and pursue product } \\
\text { quality and modernisation } \\
\text { of production lines. }\end{array}$ \\
\hline $\mathbf{E}$ & $\begin{array}{l}\text { ISO14001, } \\
\text { EHS } \\
\text { system }\end{array}$ & $\begin{array}{l}\text { Continuously follow } \\
\text { corporate policy to } \\
\text { improve cleaner } \\
\text { production activities }\end{array}$ & $\begin{array}{l}\text { Some new process } \\
\text { technology has been } \\
\text { invested and used. }\end{array}$ & $\begin{array}{l}\text { Yes, with the } \\
\text { assistance of new } \\
\text { technology used in } \\
\text { production }\end{array}$ & $\begin{array}{c}\text { GMP and } \\
\text { cGMP }\end{array}$ & $\begin{array}{l}\text { Yes, and pursue } \\
\text { modernisation of } \\
\text { production lines and } \\
\text { export performance. }\end{array}$ \\
\hline
\end{tabular}

Continued to the next page 
Continued from the previous page

\begin{tabular}{|c|c|c|c|c|c|c|}
\hline & $\begin{array}{c}\text { Q1 } \\
\text { EMS }\end{array}$ & $\begin{array}{c}\text { Q2 } \\
\text { Actions/decisions for } \\
\text { cleaner production }\end{array}$ & $\begin{array}{c}\text { Q3 } \\
\text { Specific process } \\
\text { technology for } \\
\text { cleaner production } \\
\end{array}$ & $\begin{array}{c}\text { Q4 } \\
\text { Cleaner } \\
\text { production of new } \\
\text { products } \\
\end{array}$ & \begin{tabular}{c}
\multicolumn{1}{c}{ Q5 } \\
Industrial \\
regulations \\
/legislation \\
\end{tabular} & $\begin{array}{c}\text { Q6 } \\
\text { Good global citizenship } \\
\text { and strategic importance } \\
\text { factors }\end{array}$ \\
\hline $\mathbf{F}$ & No & $\begin{array}{c}\text { Continuous } \\
\text { improvement in energy } \\
\text { consumption; } \\
\text { renovating sewage } \\
\text { treatment equipment }\end{array}$ & $\begin{array}{l}\text { Promoting } \\
\text { powder-pressing } \\
\text { produced tablets, } \\
\text { implementing the } \\
\text { dry-rolled grain } \\
\text { technology }\end{array}$ & $\begin{array}{l}\text { Yes, relying on } \\
\text { production process } \\
\text { innovation to } \\
\text { reduce dust and } \\
\text { improve output }\end{array}$ & GMP & $\begin{array}{l}\text { Yes, and pursue modern } \\
\text { pharmaceutical } \\
\text { technology/people's } \\
\text { wellbeing/health. }\end{array}$ \\
\hline $\mathbf{G}$ & No & $\begin{array}{l}\text { Implementing } \\
\text { initiatives to improve } \\
\text { process efficiency }\end{array}$ & $\begin{array}{l}\text { Implementing more } \\
\text { efficient production } \\
\text { technology to } \\
\text { generate more output } \\
\text { with less energy } \\
\text { consumption }\end{array}$ & $\begin{array}{l}\text { Yes, with process } \\
\text { innovation for } \\
\text { producing new } \\
\text { products }\end{array}$ & GMP & $\begin{array}{c}\text { Yes, and pursue modern } \\
\text { pharmaceutical technology } \\
\text { and people's } \\
\text { wellbeing/health. }\end{array}$ \\
\hline $\mathbf{H}$ & No & $\begin{array}{l}\text { No particular actions } \\
\text { and decisions taken }\end{array}$ & $\begin{array}{l}\text { No specific changes } \\
\text { in process and } \\
\text { technology }\end{array}$ & No difference made & $\begin{array}{l}\text { GMP and } \\
\text { cGMP }\end{array}$ & $\begin{array}{l}\text { Do not know, but consider } \\
\text { importance of product } \\
\text { quality/ pharmaceutical } \\
\text { technology. }\end{array}$ \\
\hline $\mathbf{I}$ & No & $\begin{array}{l}\text { No particular actions } \\
\text { and decisions taken }\end{array}$ & $\begin{array}{l}\text { No specific changes } \\
\text { in process and } \\
\text { technology }\end{array}$ & No difference made & GMP & $\begin{array}{l}\text { Think irrelevant, but } \\
\text { consider importance of } \\
\text { modernisation of } \\
\text { production lines/ } \\
\text { pharmaceutical } \\
\text { technology. }\end{array}$ \\
\hline
\end{tabular}

Table 2. The summary of responses to the six survey questions collected using the second questionnaire 
Question 5 is concerned with industrial and government regulations relating to cleaner production. The collective information by companies has confirmed the importance of the compulsory national GMP for Chinese pharmaceutical manufacturing companies. Only two companies amongst these nine have obtained cGMP. In addition, the 'Pharmaceutical Production and Quality Management Practices' provides practical guidelines consistent with GMP to pharmaceutical companies in China for pharmaceutical manufacturing companies to follow. Other regulations and relevant laws are the following, which are not listed in Table 2:

- 'Drug Administration Law of the People's Republic of China'

- 'Regulations for the Implementation of the Drug Administration Law of the People's Republic of China'

- 'The People's Republic of China-the Chinese Medicine Ordinance'

- 'Prescription drugs and non-prescription drugs category management approach (Trial)'

- 'Drug Quality Control Standards'.

Question 6 investigates whether achieving a good global citizenship is of strategic importance to the company and asks the company to specify two strategically important factors to their businesses. This question explores the company's environmental culture. Environmentallyfriendly culture can be reflected by the company's outlook towards its roles of being ethical to environment and society when conducting their business activities (Thomas, 2002). Companies $A$ to $\mathrm{G}$ all provided positive answers to the question regarding whether good global citizenship is of strategic importance to their business. To stress the importance of good global citizenship, company $\mathrm{G}$ has further emphasised that it adhered to the peopleoriented enterprise development principle to motivate employees to develop their creativity and put forward initiatives. The company also advocates 'enterprise and employee, environment and society harmony'. However, companies $\mathrm{H}$ and I did not provide positive answers to this question. Company $\mathrm{H}$ answered 'not sure' about this question and company I indicated that achieving a good global citizenship had not been given strategic importance within the company. In the second part of this question, strategically important factors were selected from the following: product quality, produce export, modernisation of production lines, modern pharmaceutical technology, western technology, people health, product to market, and market share. Modernisation of production lines, pharmaceutical technology, and production quality are the most commonly mentioned items as important to these pharmaceutical companies. A couple of companies considered export performance and people wellbeing and health as the most important to their businesses (see Table 2).

This section summarises the results collected by the six questions regarding cleaner production of the nine major Chinese pharmaceutical companies in Tianjin, China. The next section analyses these data results by discussing implications and contributions of these results to the literature in relation to the four propositions presented in the conceptual framework and the four corresponding research questions proposed at the end of the literature review section.

\section{Analysis and discussions}

The data results support the first proposition of the conceptual framework, which is the positive impact of ISO14001 certification on company cleaner production. This is consistent with the literature (Matouq, 2000; Psomas et al., 2011). The questionnaire results clearly indicate that the companies having the ISO14001 certification are more likely to be one step ahead in actively pursuing cleaner production. Further communications with ISO14001 certified companies confirmed that by pursuing an EMS at the international standard, they became more proactive to develop and implement cleaner production initiatives which lead to 
cleaner production decisions, activities and actions. These ISO14001 certified companies also asserted that being certified of ISO14001, they have systematically developed EMSs in place and made the company consider reducing wastage, pollution, and improving efficiency in the production process of strategic importance to the business.

However, not all non-ISO14001 companies have done less in terms of cleaner production, such as companies $\mathrm{F}$ and $\mathrm{G}$ which were particularly advanced in implementing eco-process innovation related cleaner production decisions, activities or actions. This indicates that ISO14001 certification is not a sole determining factor to a company's pursuit of cleaner production. This also proposes a question of what drives the non-ISO14001 certified companies to pursue cleaner production, which is discussed later in this section. Exploring the first proposition addresses the first research question regarding how ISO14001 impacts on cleaner production. It is clear that ISO14001 certification empowers the company by proactively engaging and strategically recognising the importance of cleaner production to the company.

The second proposition in the conceptual framework addresses the positive impact of ecoinnovations of product and process on cleaner production. This proposition is partially supported by the data results. The data results confirm that green process innovation has a positive impact on cleaner production decision (Dencic, et al., 2014; Ekins, 2010; Grundemann, et al., 2009). However, green product innovation alone does not always lead to effective improvement in cleaner production, if it does not go along with green process innovation. This does not support the general finding on green product innovation as the most important factor in achieving cleaner production by Dangelico and Pujari (2010). Our study reveals that process innovation drives cleaner production by improving process efficiency through green technology. Producing new or greener products without improved processes would make little difference in achieving cleaner production. Green product innovation needs to go hand-in-hand with green process innovation to be effective in cleaner production. This might be unique to the pharmaceutical industry because its products, which are drugs and medicines, cannot be readily altered except by formulating with less chemical and toxic ingredients (Fatta-Kassinos et al., 2011). However, the production process can be more dramatically modified, such as using dry-grain technology instead of the process technology which requires a large amount of water in production. It is evidenced by these case study companies that green process innovation impacts on cleaner production more profoundly than green product innovation. Whether it is unique to the pharmaceutical industry can be explored further by researching green innovation of process and product across different industries. The current findings on green process and product innovation address the second research question regarding the type of innovation impacting on cleaner production more profoundly and why. It is clear that in the pharmaceutical industry, green process innovation influences the usage of materials, water and energy in producing drugs and medicines more significantly than green product innovation.

The importance of green process innovation leads to further discussions regarding approaches along the six critical control points illustrated in the process map (Figure 1). Cleaner production decisions, activities and actions associated with critical control points of 1 to 3 at the early stages of the process are 'integrated' process-oriented approaches for cleaner production (Van Hoek, 1999). These decisions, activities and actions have reduced the wastage of water and the consumption of energy in the first place. The innovations, such as using the dry-rolled grain technology and using non-coal fired boilers have dramatically improved the process efficiency. This has resulted in less energy, water, and amount of 
auxiliary materials needed in the first place. The approaches which reduce waste generated at the control points 4 to 6 are characterised as 'end-of-pipeline' pollution control innovations (Van Hoek, 1999). These include sewage water treatment, water reuse treatment, and odour reduction treatment. These cleaner production innovations avoid some of the final wastes returning to the environment, by transforming them into re-usable materials or reducing the level of air pollution. However they do not reduce the amount of waste generated in the first place. The 'integrated' process-oriented approaches have a more profound impact on the overall environmental performance than 'end-of-pipeline' approaches (Lee and Rhee, 2005). The process map (Figure 1) can be further used to support the development of cleaner production initiatives along these six critical control points, with a particular emphasis on 'integrated' process-oriented approaches associated with the first three critical control points.

The third proposition addresses the impact of the industrial and government regulations on cleaner production. The conceptual framework considers the positive impact of industrial and government regulations, such as GMP, cGMP and the China's 'CP strategy', on cleaner production in Chinese pharmaceutical manufacturing companies. It is clear that the Chinese government and the pharmaceutical industry encourage companies to pursue international environmental standards of ISO14001 which may have an impact on their engagement of cleaner production. The data results indicate that the compulsory national GMP in the pharmaceutical industry offers good standards for product quality requirements. However it does not distinguish companies in terms of their effort in pursuing cleaner production. There are also no differences showing in terms of cleaner production effort for those two companies which have also obtained the cGMP. This addresses the third research question on how the industrial and government regulations shape cleaner production. The need for regulation is undeniable; but this research reveals that regulations alone do not distinguish the cleaner production effort among these major pharmaceutical companies in China.

The question here is what inspires non-ISO14001 certified companies to pursue cleaner production proactively. What prompted two of these non-ISO14001 certified companies to pursue their cleaner production? Proposition four addresses this by relating being active in cleaner production to an environmentally-friendly culture. This environmentally-friendly culture concerned in this study is particularly in relation to the outlook of ethical consideration of environment and strategic importance of good global citizenship of business practices. All the companies which are active in pursuing cleaner production have viewed good global citizenship of strategic importance to their business. The two companies which implemented cleaner production but without ISO14001 certification (Companies F and G) have over one hundred years' history in the pharmaceutical industry. These two companies consider people's wellbeing and health as one of the most important factors to their businesses. They promote a sustained, stable, and healthy business development. It is clear that if a company has not put environmentally-friendly culture associated outlooks, such as being a good global citizen and prioritising people's wellbeing and health, into a strategically important position, it is less likely for any environmental improvement decisions, activities or actions to be initialised and implemented. It also indicates that an environmentally-friendly culture, which is reflected by ethical consideration of business and importance of people's wellbeing and health to the business, drives a company to pursue its cleaner production. This follows the same principle that a culture supporting improvement is critical for companies to adopt management approaches (Stirzaker et al, 2011). It is particularly critical when resources may have restricted the company achieving ISO14001 certification. This may explain the difference in their cleaner production effort and indicate the importance of environmentally-friendly culture to cleaner production. This addresses the last research 
question on how the environmentally-friendly culture makes a difference in cleaner production. It is evidenced that the environmentally-friendly culture promotes an ethical business environment and the strategic importance of cleaner production in the company.

Hence, we summarise the factors impacting on cleaner production supported by the case study organisations in Figure 5.

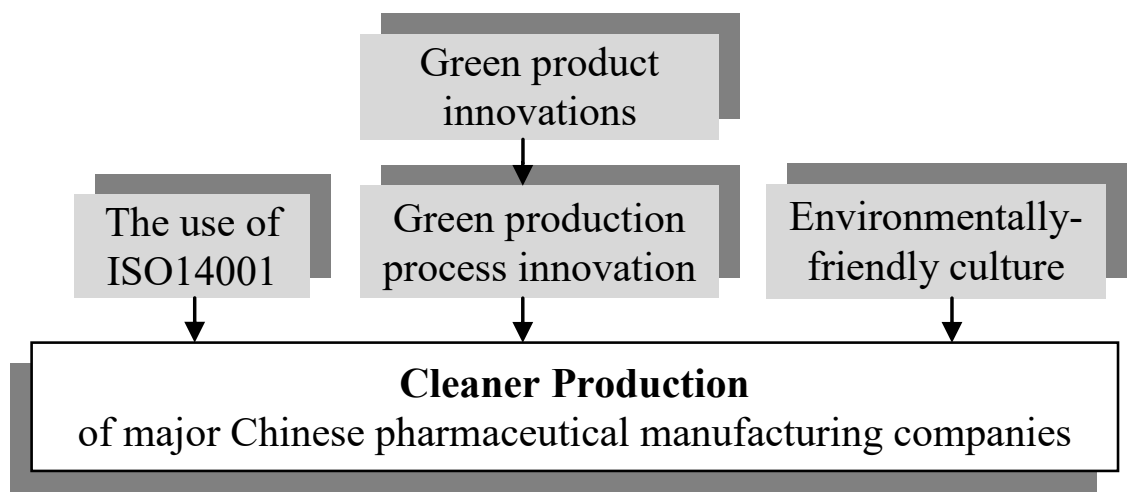

Figure 5. A summary of the findings regarding factors impacting on cleaner production

Qualitative case-study research provides good insight into the drivers of cleaner production in this specific context and allows related factors to be explored. We have conducted a single comparative case study to establish relationships between factors. Further studies can be conducted using a large sample to test and quantify these relationships. This research is theory building and refinement, and its validity and reliability lies in the quality of data collected and logic of comparison and synthesis made for improved understanding. In addition, longitudinal research within cases and large sample surveys followed by econometric modelling approach, would add further insight into the causal relationships between any of these factors and cleaner production, environmental and firm performance ( $\mathrm{Li}$ and Hamblin, 2001 and 2003). However, this is outside the scope of this research.

\section{Conclusions}

The environmental sustainability literature asserts the importance of the four factors: the use of ISO14001, eco-innovation of product and process, industrial and government regulations, and environmentally-friendly culture, to cleaner production for manufacturing companies. However, limited studies have explored these factors simultaneously impacting on cleaner production. Therefore, we have developed the four propositions associated with each of these factors in our conceptual framework and proposed research questions accordingly. A fivestep case study research model has been employed, including defining research questions, selecting companies, collecting data, analysing and comparing data to the conceptual framework, and drawing conclusions to achieve the research aim.

The companies with an ISO14001 certification are more proactive and one step ahead in developing and pursuing cleaner production. This is because they have been systematically involved in developing their EMSs and put cleaner production as strategically important in practice. Studies in other developing countries also confirm the positive influence of ISO14001 on companies (Blackman, 2012; Gavronski et al., 2013; Nee and Wahid, 2010). This implies that when the resources are available, pursuing the ISO14001 certification in manufacturing companies in developing countries is a way forward to their environmental sustainability development to gain competitive advantages. 
We note from the company profiles that not all the ISO14001 certified companies are export dominated, and we also note that the public-owned organisations do not have this certification. According to the literature, Chinese firms pursuing ISO14001 certifications were motivated by export requirements from foreign customers (Qi et al., 2011). In particular, seeking 'entrance to the international market' was identified as the major driver for Chinese firms to obtain an ISO14001 certification (Zeng et al., 2005). The experience of our case companies did not confirm that export is one key driver for pursuing ISO14001 certification. In addition, information in the company profiles confirms that private-owned companies are likely to obtain ISO14001 certification. As the factors impacting on pursuing ISO14001 certification do not fall into the scope of this paper, we suggest the exploration on how these factors impact on the pursuit of ISO14001 certification as future research opportunities.

The companies' experiences indicate that it is green process innovation which directly impacts on cleaner production in pharmaceutical manufacturing companies in China, through improved process efficiency and the use of green technology. Green product innovations alone are not adequate to make significant differences on cleaner production for these pharmaceutical manufacturing companies. Green product innovations need green process innovation to make positive impact on the environmental performance. For green process innovations, 'integrated' process-oriented approaches, which reduce the waste and pollutant emissions generated in the first place, are particularly crucial for achieving profound effects in reduction of raw materials usage, and energy and water consumption. 'End-of-pipeline' green process innovations, which treat generated waste, have a complementary role to 'integrated' process-oriented approaches in pursuing cleaner production. Understanding the process and the critical control points using the process mapping tool helps to generate innovative ideas to improving cleaner production. The industry needs to promote 'integrated' cleaner production innovations in order to achieve better environmental performance in the long-run.

It is important to conclude that it is an environmentally-friendly culture which makes the difference in terms of the companies' cleaner production, besides ISO14001 certification. If the culture does not support ethical consideration of environment and society, it is unlikely that the company promotes cleaner production to improve their environmental performance. A pharmaceutical company which has a long history appears to inherit its traditional ethical value of good citizenship and contribute to the society and environment with harmony. This encourages the company to proactively pursue cleaner production. Future research can explore which culture dimensions (Ginevičius and Vaitkūnaite, 2006) constitute the environmentally-friendly culture and how such culture dimensions can be developed. The importance of developing an environmentally-friendly culture is particularly useful for those recently established companies which are not yet ISO14001 certified.

This research also reveals that while industrial and government regulations such as GMP and 'the CP strategy' are essential to ensure that the industry maintains threshold production quality standards, such regulations do not mandate companies' cleaner production efforts. Future studies can be considered on what are included in the current environmental regulations and what else should be developed in these regulations to influence the company's effort in pursuing cleaner production. This can lead to constructive suggestions on how to develop the current regulatory framework further to encourage companies to proactively engage in development of cleaner production. This will influence policy makers 
when setting and updating industrial and government regulations to raise the current thresholds in order to have a more profound environmental impact in future.

This research contributes to the literature of the cleaner production and environmental sustainability in general, through theory building and refinement. In particular, it improves the understanding of factors impacting on cleaner production. The findings on the essential position of green process innovation clarify some differences presented in the literature and also propose some questions for further exploration. The identified factors impacting on cleaner production propose the further research areas associated with these factors across other industries and different countries. Further research can be conducted to establish whether the conclusions of the relationships between these factors and cleaner production can be generalised elsewhere in China, other industries, or in other developing countries. Further research can also be made to compare these relationships in developing and developed countries. Econometrical modelling using large quantitative surveys can be conducted to evaluate causal relationships and effect sizes of these factors on cleaner production performance, or action research to explore the changes over time in the pharmaceutical industry or different industries and countries.

It would also be interesting to explore the inter-relationships between eco-innovation of product and process, ISO14001 certification, and environmentally-friendly culture and how cleaner production impacts on the environmental and business performance. However, studying the inter-relationships between these factors and relationships between cleaner production and environmental and business performance are outside the scope of this research. Further studies can explore the inter-relationships among these factors and relationships between cleaner production and environmental and business performance to address these dimensions for further enhanced cleaner production and environmental sustainability development.

\section{Acknowledgment}

- The assistance of Professor Jie Zhang, Professor Yumei Li, and the Principal Mr Xiaoshong Liu of the Tianjin Biotechnology Institute in capturing the company data and providing other relevant information is gratefully acknowledged.

- The invaluable comments from the anonymous reviewers and the Editor in Chief for us to improve the original submitted paper to the current publishable form are greatly appreciated.

\section{References:}

Amstead, B.H., Ostwald, P.F., Begeman, M.L., 1987. Manufacturing processes. $8^{\text {th }}$ Edition, Wiley.

Abreu, M.C. Sá de, 2009. How to define an environmental policy to improve corporate sustainability in developing countries. Bus. Strat. Environ. 18, 542-556.

Ajami, R.A., 2007. The path to environmental sustainability and global citizenship: tentative observation on China and India. J. Asia-Pacific Bus. 8(3), 1-4.

Altenburg, T., Schmitz, H., Stamm, A., 2007. Breakthrough? China's and India's transition from production to innovation. World Dev. 36(2), 325-344.

Blackman, A., 2012. Does eco-certification boost regulatory compliance in developing countries? ISO 14001 in Mexico. J. Regul. Econ. 42, 242-263.

Chowdary, B.V., George, D., 2012. Improvement of manufacturing operations at a pharmaceutical company, a lean manufacturing approach. J. Manuf. Tech. Manag. 23(1), 56-75. 
Dangelico, R.M., Pujari, D., 2010. Mainstreaming green product innovation: why and how companies integrate environmental sustainability. J. Bus. Ethics. 95, 471-486.

Deltas, G., Harrington D.R., Khanna, M., 2014. Green management and the nature of pollution prevention innovation, Appl. Econ. 46(5), 465-482.

Dencic, I., Ott, D., Kralisch, D., Noel, T., Meuldijk, J., de Croon, M., Hessel, V., Laribi, Y., Perrichon, P., 2014. Eco-efficiency analysis for intensified production of an active pharmaceutical ingredient: a case study, Organic Process Res, Develop. 18(11), 13261338.

Department of the Environmental-Industrial Profile, 1995. Chemical works-pharmaceutical manufacturing works, Crown.

Ekins, P., 2010. Eco-innovation for environmental sustainability: concepts, progress and policies. Int. Econ. Econ. Policy. 7, 267-290.

Fatta-Kassinos, D., Meric, S., Nikolaou, A., 2011. Pharmaceutical residues in environmental waters and wastewater: current state of knowledge and future research. Anal Bioanal Chem. 399 (2), 251-275.

Fraj. E., Martínez, E., Matute, J., 2011. Green marketing strategy and the firm's performance: the moderating role of environmental culture. J. Strat. Market. 19(4), 339-355.

Gavronski, I., Paiva, E.L., Teixeira, R., Ferreira de Andrade. M. C., 2013. ISO 14001 certified plants in Brazil - taxonomy and practices. J. Clean. Prod. 39, 32-41.

Ginevičius, R., Vaitkūnaite, V., 2006. Analysis of organizational culture dimensions impacting performance. J. of Bus. Econ. \& Manag. 7(4), 201-211.

Grundemann, L., Fischer, N., Scholl, S., Hessel, V., 2009. From macro batch to micro-conti manufacturing: a new eco-friendly production process for writing ink employing microprocess engineering. Chem. Eng. Technol. 32(11), 1748-1756

Hong, J. and Li, X., 2013. Speeding up cleaner production in China through the improvement of cleaner production audit. J. Clean. Prod. 40, 129-135.

Hu, M., Phillips, F., 2011. Technological evolution and interdependence in China's emerging biofuel industry. Technol. Forecast. Soc. 78, 1130-1146.

Kesidou, E., Demirel, P., 2012. On the drivers of eco-innovations: empirical evidence from the UK. Res. Policy. 41, 862-870.

Khan, Z., 2008. Cleaner production, an economical option for ISO certification in developing countries. J. Clean. Prod. 16, 22-27.

Kim, E-H., 2013. Deregulation and differentiation: incumbent in green technology. Strat. Mgmt J. 34, 1162-1185.

Kreisberg, J. and Zheng, C., 2011. Managing unused pharmaceuticals in a hospice setting: a pilot study. Am. J. of Hosp. Palliat. Me. 28(8), 536-538.

ISO14001, 2004. Environmental management systems - requirements with guidance for use. British Standard. International Organisation for Standardization.

ISO survey, 2012. Accessed at April, 2014. The ISO 14001 survey 2012. Available at http://www.iso.org/iso/home/standards/certification/iso-survey.htm.

Lacy, P., Hayward, R.A., 2011. New era of sustainability in emerging markets? Insight form a global CEO study by the United Nations global compact and Accenture. Corp. Gov. 11(4), 348-357.

Lee, S.Y., Rhee, S.K., 2005. From end-of-pipe technology towards pollution preventive approach: the evolution of corporate environmentalism in Korea. J. Clean. Prod. 13, 387-395.

Li, X. and Hamblin, D., 2001. Developing a multivariate manufacturing company performance model: effects of technology and investment on two-dimensional firm performance. Int. J. of Prod. Res. 39(13), 2895-2912. 
Li, X. and Hamblin, D., 2003. The impact of performance and practice factors on UK manufacturing companies' survival. Int. J. of Prod. Res. 41(5), 963-979.

Liang, K., 2006. Good Manufacturing Practice in China: a brief introduction. Pharm. Technol. May. 30(5), 114-114.

Lober, D.J., 1998. Pollution prevention as corporate entrepreneurship, J. Organ. Change Manag. 11, 26-37.

Massoud, M.A., Fayad, R., Kamleh, R., El-Fadel, M., 2010. Environmental Management System (ISO 14001) certification in developing countries: challenges and implementation strategies. Environ. Sci. Technol. 44(6), 1884-1887.

Matouq, M., 2000. A case-study of ISO 14001-based environmental management system implementation in the People's Republic of China. Local Environ. 5(4), 415-433.

Melnyk, S.A., Sroufe, R.P., Calantone, R., 2003. A model of site-specific antecedents of ISO14001 certification. Prod. Oper. Manag. 12, 369-385.

Meredith, J., 1998. Building Operations Management theory through case and field research. J. Oper. Manag. 16, 441-454.

Nee, G.Y., Wahid, N.A., 2010. The Effect of ISO 14001 environmental management system implementation on SMEs performance: an empirical study in Malaysia. J. Sustain. Devel. 3(5), 215-220.

Ortolano, L., Cushing, K. K., Warren, K. A., 1999. Cleaner production in China. Environ. Impact Ass. Rev. 19, 432-436.

Psomas, E.L., Fotopoulos, C.V., Kafetzopoulos, D.P., 2011. Motives, difficulties and benefits in implementing the ISO 14001 environmental management system. Manag. Environ. Qual. An Int. J. 22(4), 502-521.

Qi, G.Y., Zeng, S.X., Tam, C.M., Yin, H.T., Wu, J.F., Dai, Z.H., 2011. Diffusion of ISO 14001 environmental management systems in China: rethinking on stakeholders' roles. J. Clean. Prod. 19, 1250-1256.

Ren, J., Zhang, L., Wang, R., 2010. Measuring the sustainability of policy scenarios: Emergy-based strategic environmental assessment of the Chinese paper industry. Ecol Complex. 7, 156-161.

Romli, A., Prickett, P., Rossitza, S. Shwe, S., 2015. Integrated eco-design decision-marking for sustainable production development. Int. J Prod. Res. 53(2), 549-571.

Schumacher, I., 2015. The endogenous formation of an environmental culture. Euro. Econ. Rev. 76, 200-221.

Searcy, C., Morali, O., Karapetrovic, S., Wichuk, K., McCartney, D., McLeod, S., Fraser, D., 2011. Challenges in implementing a functional ISO 14001 environmental management system. Int. J. Qual. Reliab. Manag. 29(7), 779-796.

Seuring, S.A., 2008. Assessing the rigor of case study research in supply chain management. Supply Chain Manag. An Int. J. 13, 128-137.

Shields, P.M., 1998. Pragmatism as a philosophy of science: a tool for public administration. Res. Public Admin. 4, 195-225.

Stirzaker, R.J., Roux, D.J., Biggs, H.C., 2011. Learning to bridge the gap between adaptive management and organisational culture. Koedoe: Afr. Prot. Area Conser. and Sci. 53(2), 1-6.

Stone, L., 2000. When case studies are not enough: the influence of corporate culture and employee attitudes on the sccess of cleaner production initiatives. J. Clean. Prod. 8, 353359.

Stuart, I., McCutcheon, D., Handfield, R., McLachlin, R., Samson, D., 2002. Effective case research in Operations Management: a process perspective. J. Oper. Manag. 20, 419433. 
Suthar, S., Singh, D., 2012. Phytotoxicity of composted herbal pharmaceutical industry wastes. Environ. Sci. Pollut. Res. 19, 3054-3059.

Testa, F., Styles, D., Iraldo, F., 2012. Case study evidence that direct regulation remains the main driver of industrial pollution avoidance and may benefit operational efficiency. J. Clean. Prod. 21, 1-10.

Thomas, R., 2002. A greater understanding of environmental ethics and need for inculcating environment-friendly culture. Int. Rev. Sociol. 12(1), 77-87.

Van Hoek, R.I., 1999. From reversed logistics to green supply chains. Supply Chain Manag. An Int. J. 4(3), 129-134.

Vastag, G., Melnyk, S.A., 2002. Certifying environmental management systems by the ISO 14001 standards. Int. J. Prod. Res. 40(18), 4743-4763.

Vieira, L.C., Amaral, F.G., 2016. Barriers and strategies applying Cleaner production: a systematic review. J. Clean. Prod. 113, 5-16.

Vogel, D., 1998. The globalization of pharmaceutical regulation. An Int. J. Policy Admin. 11 (1), 1-22.

Voss, C., Tsikriktsis, N., Frohlich, M., 2002. Case research in Operations Management. Int. J. Oper. Prod. Manag. 22(2), 195-219.

Vries, H,J. de, Bayramoglu, D.K., Wiele, T. van der, 2012. Business and environmental impact of ISO 14001. Int. J. Qual. Reliab. Manag. 29(4), 425-435.

Wang, X., Hong, J., Liu P., 2010. Research on technological innovation capability evaluation of Guangxi pharmaceutical industry. Int. J. Bus. Manag. 5(1), 176-180.

Wang, J., 1999. China's national cleaner production strategy. Environ. Impact Assess. Rev. 19, 437-456.

World Bank Data, http://data.worldbank.org/indicator/CM.MKT.LDOM.NO/countries. Last access on the $8^{\text {th }}$ August, 2015.

Yang, X., Yao, Y., 2012. Environmental compliance and firm performance: evidence from China. Oxford B. Econ. Stat. 74 (3), 397-424.

Yu, F., Chen J., Sun, F., Zeng, S., Wang, C., 2011. Trend of technology innovation in China's coal-fired electricity industry under resource and environmental constraints. Energ. Policy. 39, 1586-1599.

Yu, Y., Wen, Z., 2010. Evaluating China's urban environmental sustainability with data envelopment analysis. Ecol. Econ. 69, 1748-1755.

Zeng, S.X., Tam, C.M., Tam, V.W.Y., Deng, Z.M., 2005. Towards implementation of ISO 14001 environmental management system in selected industries in China. J. Clean. Prod. 13, 645-656.

Zhang, W., Wang, W., and Wang, S., 2014. Environmental performance evaluation of implementing EMS (ISO 14001) in the coating industry: case study of a Shanghai coating firm. J. Clean. Prod. 64, 205-217.

Appendix 1: Questions for producing company profiles

1. Company name

2. Company ownership

3. Establishment year

4. The number of employees

5. Whether export and countries of exporting, if yes

6. Product range

7. Product types: traditional Chinese medicines (TCM), Modern Chinese Medicines, Western medicine, processed pharmaceutical raw materials, and/or intermediates

8. GMP and cGMP certification, yes or no, which year

9. ISO9000 and ISO14000 certification, yes or no, which year 
Appendix 2: Survey questions, used for this paper, for cleaner production related aspects of pharmaceutical companies in Tianjin, China

1. Does your company have an environmental management system in use? If yes, please specify it.

2. What has your company implemented in the past five years in relation to cleaner production (environmental sustainability development)?

3. What specific technologies or processes has your company employed in order to achieve cleaner production (environmental sustainability) requirements or targets set in the government policies/regulations?

4. In comparison to producing old products, is producing new products greener and cleaner, such as, using less raw ingredients, particularly auxiliary materials for producing Chinese medicines, generating less toxic substances, reducing carbon dioxide emissions, or any other reduction of negative impacts on the environment?

5. Please specify the industrial and government regulations/policies which are directly relevant to your company.

6. Is achieving a good global citizenship relevant to your company's strategic planning? In addition, please select two most important aspects to your company from the following: product quality, product export, modernisation of production lines, modern pharmaceutical technology, western technology, people health, products to market, market share, or others, please specify. 